\title{
The Rise and Decline of Chinese Opera in Indonesia*
}

\author{
Tao Zhang \\ Overseas Education College \\ Xiamen University \\ Xiamen, China 361102
}

\begin{abstract}
There are two types of Chinese Opera in Indonesia: the Chinese local opera and Malayu opera. This article attempts to trace the historical process of Chinese Opera in Indonesia, analyzes the concerning questions, supplies some materials for further study on the oversea spreading of Chinese opera and its localization as Malayu opera.
\end{abstract}

\section{Keywords-Indonesia; Chinese; opera; Malay opera}

\section{INTRODUCTION}

Chinese immigrants moved south to Indonesia, which can be traced back to the Tang Dynasty. In the Ming Dynasty, Chinese immigrants settled in Indonesia have taken shape. Some traditional local operas in China, especially in Guangdong and Fujian and other coastal cities, have been introduced to Indonesia from the early Qing Dynasty, and blended with traditional Indonesian operas, becoming a part of local multicultural organism. The Indonesian Chinese opera can be divided into two types. One is the primary Chinese opera, and the other is the localized Chinese opera which is performed by the language of Malayu.

\section{MALAY ChINESE OPERA OF INDONESIAN CHINESE}

Indonesian Malayu is also known as "popular Malayu language". Compared with the Indonesian aristocratic Malayu, it is characterized by a mixture of Malayu, Chinese, Indonesian dialects, Dutch and English, and a lot of Fujian dialects. In the Nineteenth Century, all sectors of people in Indonesian society widely used this kind of language in communication. Native Chinese writers also used the language for opera creation. Chinese Malayu opera is a unique opera type, which is considered to be unorthodox for a long time without being paid attention. In 1981, Claudine - Salmon, French Female Scholar, published a novel "Chinese Malayu Literature in Indonesia" in Paris, with a surprising number of rich and detailed data. It convincingly demonstrated the historical status and contribution of the Malayu literature, which has attracted the attention of international academic circles. According to Salmon's incomplete statistics, there are 806 native Chinese writers and translators born in Indonesia, with a total of 3005 works. Among them, there are 73 opera books. Some of these opera books are wrote in the pattern of script, and provided to amateur opera troupe for fund-raising performance. They are used for raising fund for charity. Some are of the need for

*This article is the stage achievement of the annual national art science project for the tenth five-year plan titled in "the history of Chinese opera in Southeast Asia"). literature. ${ }^{1}$ As literary script, they are only available to the reader. Some are special for the performance of professional opera troupe, and could be adapted according to the needs of actors, dance and realist events at that time.

Indonesian Chinese Malayu opera starts from 1880s. At that time, they mainly translated Chinese classical operas, such as, Chen San and Wu Niang (1886), Bao Gong Case (1887), Generals of Yang Family (1887) and Mulan (1893). ${ }^{2}$ These Chinese classical masterpieces first spread in the form of "puppet show" for more than half a century, and become an indispensable part of Indonesian Chinese cultural life at that time. Every Chinese New Year and other festive days, all temples would launch various forms of entertainment. In Batavia (now Jakarta), Chinese puppet shows were often given. In some busy streets, also often appear some drum entertainers. The storytelling contents are also collected from Chinese classical novels. Among these stories, Liang Shanbo and Zhu Yingtai is the most widely circulated and most far-reaching one. "There is no doubt that for the Chinese living in Indonesia the legend has been spread mouth to mouth and known to every family before the appearance of the translation of Java script and Bali script. In the early 19th Century and 20th Century, storytelling, puppet play and opera had a very important influence in the artistic life of the Chinese Indonesians. ${ }^{3}$

In 1906, the native Chinese class founded an opera troupe called SOEI BAN LIAN. People called it TJIA-IM. The owner was Shen Demei. They performed Wang Zhaojun's Distant Marriage, Madame White Snake, Xue Rengui, Liang Shanbo and Zhu Yingtai and other operas. After that native Chinese Indonesian founded a lot of opera troupe. They often selected the familiar places to perform publicly, and performing

Lin Wanli. Malayu Literature of Indonesian Chinese, recorded in works of Yegu - Sumaer. Translated by Lin Wanli. Research on Malayu Literature of Indonesian Chinese. Huoyi Publishing Business Co. Ltd., October 1998, Page 18.

Lin Wanli. Malayu Literature of Indonesian Chinese, recorded in works of Yegu - Sumaer. Translated by Lin Wanli. Research on Malayu Literature of Indonesian Chinese. Huoyi Publishing Business Co. Ltd., October 1998, Page 19 - 20.

[Australia] George Quinn. Liang Shanbo and Zhu Yingtai - a Chinese folk love stories in Java and Bali, recorded in [French] Claudia Salmon, Yan Bao's translation in Chinese Tradition Novels in Asia, International Culture Press, 1989. Quoted from Wang Lieyao and Kong Xiangwei's Rewriting Love Stories in China in Memory - a popular narrative in Indonesian Chinese literature, recorded in Journal of Jinan University (HUMANITIES AND SOCIAL SCIENCES EDITION), 2004, Issue 4, Page 73. 
contents mainly were Chinese classic stories ${ }^{4}$. These stories reflect oppressed people against the dark rule of the feudal struggle, or whip feudal code of ethics destroying young men and women, or praise upright, selfless and indomitable spirit and rites Confucius and Mencius advocate in their theories. Native Indonesian Chinese love to see and hear these stories for they encourage them to survive and develop in alien land. This is also an important reason why Indonesian Chinese have set off the upsurge of Chinese classics translation.

From the translation to the adaptation, the classical Chinese opera stories tend to have an obvious localization tendency. In order to cater to the audience, the stage performances are flexible in form. They often use traditional Indonesian opera forms people are familiar and love to perform Chinese classical opera. It often produces new content and has a new taste. "Oral circulated story of Liang Shanbo and Zhu Yingtai originally appeared in Stambul, also known as Bang Sawa, and Sandi Wata. In reserved Stambul plays, this story has a prominent position". 5 This form of art integrates Chinese opera and local Indonesian play together, and is deeply loved by the Indonesian Chinese and the local people. There is a kind of Indonesian Peking Opera, which is performed in Indonesian. It was first performed among Indonesian Chinese. There is a Ketobera play in Indonesia. The themes are very extensive, including historical stories and folk legends, modern life fragments and many adapted Chinese opera. For example, localized Chinese opera Xue Rengui and adapted it into Ketobera play. In the play Xue Rengui was renamed to Sudiro Prono. The adapted Ketobera play was performed in the folk and also very popular. ${ }^{6}$

Theatrical performances are popular among different ethnic groups in Indonesia. In early 1891, there appeared a kind of opera troupe, called "STAMBOEL", similar to Chinese touring troupe. They gave touring performances on the small and medium-sized cities in Indonesia. People gradually know and love them. In 1910, the small and medium-sized cities began to appear a play called "KOMEDIE", which was equivalent to comedy. There were no script for touring performance and comedy. In 1910, "TONEEL" (Dutch: Drama) appeared in the Dutch society and Indonesia intellectuals. In the Chinese society appeared "OPERA DERMA". These scripts were provided to charity for fundraising performances, so they were also called "fundraising drama". In 1925, 1950 and 1970, respectively appeared "SANDIWARA", "DRAMA" and "TEATER". Their names are different, but in fact, they are largely identical with only minor differences. These plays are

[Indonesia] Yegu • Sumaer. The First Opera Script in Indonesia, recorded in works of Yegu - Sumaer. Translated by Lin Wanli. Research on Malayu Literature of Indonesian Chinese. Huoyi Publishing Business Co. Ltd., October 1998, Page 61.

[Australia] George Quinn. Liang Shanbo and Zhu Yingtai - a Chinese folk love stories in Java and Bali, recorded in [French] Claudia Salmon, Yan Bao's translation in Chinese Tradition Novels in Asia, International Culture Press, 1989. Quoted from Wang Lieyao and Kong Xiangwei's Rewriting Love Stories in China in Memory - a popular narrative in Indonesian Chinese literature, recorded in Journal of Jinan University (HUMANITIES AND SOCIAL SCIENCES EDITION), 2004, Issue 4, Page 73.

Liang Minhe and Kong Yuanzhi, Indonesian Culture and Society, Beijing: Peking University Press, August 2002, Page 216 - 217. performed by artists on the stage with the form of story. It is essentially "drama".

In the late Nineteenth Century and early Twentieth Century, Chinese theatrical troupes in Indonesia were all professional. Their performances were basically not based on the fixed literary script, but on the free exertion of actors. In 1911, there appeared Chinese amateur theatrical troupes organized by Chinese charities. They couldn't play like professional actors. They needed script for rehearsals and performances. In order to get a more sound development of drama at that time, some Chinese Malayu writers began to write scripts, and offered them to the amateur dramas enthusiasts at that time. Therefore, in the first half of the Twentieth Century, the Indonesian Chinese Malayu drama was developed flourishingly.

The first Malayu script for performances of amateur troupes was "Dangerous Wealth", published by Batavia Huaxiang Printing Press in 1912. The long complete title is script of fundraising play of Chinese Dekelong Renhe Society, a story of dangerous wealth; a good admonishment will become a model. The author is unknown, and the purpose of the performance is to raise money for charity. This is a script created for the need of rehearsal, so it explains how to open and close curtains, and the rules that the actors should follow on the stage. The play followed the style of urban traditional drama of that times that actors made a self introduction to the audience whenever a new role came out. There are many beautiful scenes in the play and the sound of singing for coordination of the actors, which could create a quiet romantic atmosphere. It was the way of expression of the traditional drama at that time. For example, when Shen Guayao dated with his widowed sister-in-law in the garden, they talked love in the form of antiphonal singing. In other different scenes, singings were often interweaved. ${ }^{8}$

The early Twentieth Century was the most prosperous period of Chinese Malayu plays in Indonesia. The main dramatists were Li Jinfu, Guo Dehuai, Bao Qiu'an, Chen Wenxuan, Yang Zhongsheng and so on.

Li Jinfu (1853-1912) was the first Chinese Indonesian Malayu writer. He has published 28 Malayu literature works, and is known as "the father of Chinese Malayu Literature". He ever adapted a long narrative Malayu poem Adur Muerk into script of Sidi Akbari. During 1922, there were three editions. To 1930s, this play was adapted by Bureau of Books, and was made into movie at the late 1930s. He also organized a "Sidi Akbari" troupe, and gave touring performances in different places. Dialogues of this play were singing in the form of poem, accompanied by similar music in "Jakarta Kang List". This is a product of the combination of Chinese music and Malayu music, with a rich Chinese flavor in melody. He also founded "my refreshing" band, playing all kinds of European

[Indonesia] Yegu • Sumaer. Fake God, Published in 1919 - First Script of Guo Dehuai, recorded in works of Yegu - Sumaer. Translated by Lin Wanli. Research on Malayu Literature of Indonesian Chinese. Huoyi Publishing Business Co. Ltd., October 1998, Page 37.

[Indonesia] Yegu • Sumaer. The First Opera Script in Indonesia Dangerous Wealth, published in 1912, recorded in works of Yegu • Sumaer. Translated by Lin Wanli. Research on Malayu Literature of Indonesian Chinese. Huoyi Publishing Business Co. Ltd., October 1998, Page 62 - 65 
instruments. ${ }^{9}$ Guo Dehuai (1886-1952) was the founder of "Drama Treasure". He published a total of eight plays of separate edition. The famous plays are Fake God (1919), Victim of "Public Welfare" (1926), the Living Corpse (1931), Thief (1935), the Most Valuable Ornament (1936), Pepper Corn (1936) and so on. ${ }^{10}$ Fake God: a comedy of six scenes was adapted from Philippe Oppenheim's short story Fake God. The play is widely spread among Chinese amateurs and has a great influence. ${ }^{11}$ The play of Bao Qiu'an (1906-1981) has a strong Christian flavor. The main scripts include Why do We Live (1937), Mother or Husband (1938), The Inextinguishable Fire (1939), Women's Heart (1940), Secret of Dr. Wang (1941), etc. $^{12}$

Different scholars hold different opinions on the end time of the Indonesian Chinese Malayu drama creation. Liang Youlan believes that at the beginning of 1942, Holland's colonial rule in Indonesia collapsed. During the Japanese's occupation of Indonesia, the native Chinese writers have completely stopped using "low Malay" for creative activity. Guo John, Chinese scholar living in New Zealand, also held the same view. ${ }^{13}$ But Salmon's opinion was quite different, and thought the end time was in the early 1960s. Liao Jianyu believes that the political incident of Indonesian Communist Party, on September 30, 1965, led to the collapse of the Indonesian Communist Party. The pro-co-writers (including Chinese pro-co-writer) were suppressed in Indonesia. This "Jiuzhou Political Incident" finally ended native writers' Malayu drama creation. ${ }^{14}$

\section{THE ORIGIN AND REVITALIZATION OF CHINESE OPERA IN INDONESIA}

Chinese local operas were introduced into Indonesia at the end of the Qing Dynasty. Among them, Gaoja opera was most frequently performed, lasted for the longest time and had the richest plays and the greatest influence. From the 14th Daoguang year to 24th Daoguang year (1834-1844), Fujinxing Troupe first went to the Southeast Asia to play Gaoja opera, which was welcomed by Indonesian oversea Chinese. ${ }^{15}$ In the

[Indonesia] Yegu • Sumaer. Father of Chinese Malayu Literature, recorded in works of Yegu $\bullet$ Sumaer. Translated by Lin Wanli. Research on Malayu Literature of Indonesian Chinese. Huoyi Publishing Business Co. Ltd., October 1998, Page 53 - 54.

10 [Indonesia] Yegu $\bullet$ Sumaer. Golden Age of Popular Malayu Literature, recorded in works of Yegu $\bullet$ Sumaer. Translated by Lin Wanli. Research on Malayu Literature of Indonesian Chinese. Huoyi Publishing Business Co. Ltd., October 1998, Page 13.

11 [Indonesia] Yegu • Sumaer. Fake God, Published in 1919 - First Script of Guo Dehuai, recorded in works of Yegu $\bullet$ Sumaer. Translated by Lin Wanli. Research on Malayu Literature of Indonesian Chinese. Huoyi Publishing Business Co. Ltd., October 1998, Page 39 - 42.

12 Wu Peifang. Study of Oversea Performance of Anti-Japanese Drama - Taking local operas of coastal areas as example from 1937 to 1945. Fuxinggang Journal, 2005, Issue 83, Page 158.

13 Liang Youlan. Chinese Literature in Indonesia, Jakarta Gunon Argonne Publishing House, 1962, Page 156 - 169. Quoted from Indonesian Culture and Society, edited by Kong Yuanzhi and Liang Minhe, Peking University Press, August 2002, Page 173.

14 Liao Jianyu. Current Literature of Oversea Chinese in Indonesia, published in Lianhe Zaobao, June 11, 2001.

15 Chen Lei, Liu Xiangru, Lin Ruiwu. Fujian's Local Operas. Fujian People's Publishing House, July 1997, Page 41. period of 1870-1880, ${ }^{16}$ Fujian's troupe of Gaoja opera and puppet show "You Fu" frequently went to Chinese communities in Indonesia for performances. They performed Fighting Lv Bu for Three Times, Zhao Yun Saves Master, Wu Song Kills Sister-in-law, Liang Shanbo and Zhu Yingtai. 3 The troupes of Gaoja opera's performances in Indonesia continued to 1930s. It lasted for a hundred year. Plays of each troupe were different, and they had a strong cast. Especially actors of clown role made a brilliant figure and had unique skills, creating a superb clown art. ${ }^{17}$

With the spread of opera in Indonesia, some Chinese troupes have also appeared in Indonesia. According to historical records, in 1847 appeared an actor death case caused by shipwreck in congratulating Hong Rong's birthday. Niangzai Naore, also known as Zhong Heniang, was captain of the Chinese opera troupe at that time. "In Niangzai Naore's troupe, there were children's performances. Their equipment (ornaments and dress) was quite complete. If anyone wants to invite them for performance, he shall carry their actors and stage properties to the performing place and send them back after performance. Be sure to comply with requires for the sake of the troupe's convenience". ${ }^{18}$ In October 1846, Huang Rong celebrated his birthday, so he invited the troupe for performance. Originally they invited the troupe to perform for five days. But for only three days, Huang Rong arranged to carry the troupe back. "There were six actors, including $\mathrm{Na}$ Huye, Ran Mei, Wu Ji, Shi Dong and Na Xiye. There were also Ma Zhima, Ma Nanmei, Ren Long, Si Wen, Si Rong, a man and a woman, and a free rider, called Zhenniang. They all had equipment, and they overloaded the vessel". ${ }^{19}$ Halfway across the way, "the vessel began to sink. The people in the vessel and properties and all music instruments also sank into the sea. Na Huye, Si Bang Ma Zhima and Zheniang died. The other people escaped. Huang Rong failed to keep the agreement and let actors come back, so led to a disaster. So, he shall compensate for all damages". ${ }^{20}$ Seen from the detailed list of lost articles, this troupe has complete equipment, props, clothing and ornaments. It's quite amazing at that time. We can see current situation of Chinese troupes in Indonesia at that time.

In addition to Gaoja opera, Teochew opera, Qiong opera and Hanchu operas of Fujian and Guangdong also were introduced and rooted in Indonesia earlier. After 1851, Laoshuangxi Troupe and Laozhenghe Troupe, Teochew opera

16 Liang Liji. History of Indonesian Literature II, Kunlun Press, September 2003, Page 343.

17 Main Performance Situation of Each Opera Troupe at that Time. See: Chen Lei, Liu Xiangru, Lin Ruiwu. Fujian's Local Operas. Fujian People's Publishing House, July 1997, Page 41 - 43. Lai Bojiang. Overview of Chinese Opera in Southeast Asian, Chinese Opera Press, January 1993, Page 191 - 192.

18 Wu Fengbin, [Dutch] Chen Menghong, [Dutch] Bao Leshi, Nie Dening: Chinese Council in Batavia (Batavia Tribunal) Archives Series Case Book (fifth series), Xiamen: Xiamen University Press, Dec. 2005, Page 141.

19 Wu Fengbin, [Dutch] Chen Menghong, [Dutch] Bao Leshi, Nie Dening: Chinese Council in Batavia (Batavia Tribunal) Archives Series Case Book (fifth series), Xiamen: Xiamen University Press, Dec. 2005, Page 141.

20 Wu Fengbin, [Dutch] Chen Menghong, [Dutch] Bao Leshi, Nie Dening: Chinese Council in Batavia (Batavia Tribunal) Archives Series Case Book (fifth series), Xiamen: Xiamen University Press, Dec. 2005, Page 141. 
troupes of Guangdong, took Bangkok as center and often went to Indonesia for performances. ${ }^{21}$ After that some famous Qiong opera artists, including Dawu Wu Shenggui, Xiaowu Yu Gang, Wuchou Li Shenzhen, Wudan Zheng Hongming, Feng Yi, Sai Yuqiong and Xin Zhoumei, Dahualian Fu Qing, Chou Che Dapao, Qi Guang, Chen Leyuan, Sheng Huang Yincai, Chen Xueli, Li Jijin, Zheng Changhe, Dan Rui Lan, Li Fenglan,, Wang Kenxiang, Zhang Lujin, Chen Chenggui, Sai Jiao and Wang Fengmei, Jing Fa Qi, and Xusheng Luan Qi, repeatedly came to Southeast Asian countries including Indonesia for performence. ${ }^{22}$ Han opera is also known as "Waijiang opera". Many oversea Chinese, original native of Guang Dong, spoke Hakka in Indonesia. In the early years of Qing Xuantong, Laosanduo, a Waijiang opera troupe with hundreds of actors, went to Indonesia for performance and was very popular. ${ }^{23}$ In 1921, Xintiancai, a Han opera troupe of Guangdong, went to Indonesia for performance. Xiaosheng Lai Xuan was famous in this troupe because of his marvelous voice with an extraordinary range. Someone described it with a verse: "Lai Xuan's singing is like echo of valley. People, five miles away, can hear and are touched". His representative plays include Lu Hua Xue, Making Zhou Yu Angry for Three Times, Shooting Halberds to Yuanmen, Writing Complaint with Cinnamon Branch and Killing Wang Mang. Huadan Qiu Saihua was famous for her rich and exquisite feelings in the performance. Her representative plays were Drunken Concubine, Xue Jiao Eating Pearl and Zhuang Zi Fanning Grave. Xintiancai had played for nearly three months in Jakarta, and the opera house was packed every time. ${ }^{24}$ In 1928 , some Guangdong opera troupes in Singapore, including two troupes in Pulau Pe-nang, often gave tour performances among Malaysia, Singapore and Indonesia Sandakan. ${ }^{25}$

Under the influence of Chinese troupes, Indonesian Chinese opera lovers had set up Hongyishun Society, Bifeng Society and other amateur troupes. ${ }^{26}$ In addition, other Hanopera amateur troupes and Han-music troupes were Jiaoling Townee Association, Dapu Townee Association, Songkou Townee Association, which had a great influence on the society. There were Han opera and Han music organizations in all places Chinese people lived. These organizations tended to decline in the 1960s and were gradually revived after 1970s and 1980s. For example, they set up Xintong Music Association in Xintong Port in the west Java. Both professionals and amateurs of Han opera and Han music from Guangzhou and Chaozhou could join in the club. In Bandung, Bogor, Sujiayamei, Tasikmalaya, Qiandongxu and other places,

21 Lai Bojiang. Overview of Chinese Opera in Southeast Asian, Chinese Opera Press, January 1993, Page 180.

22 Lai Bojiang. Overview of Chinese Opera in Southeast Asian, Chinese Opera Press, January 1993, Page 181.

23 Spread to Foreign Countries. Hubei Historical Accounts of Past Events, Z1, 1998, Page 198

24 Lai Bojiang. Overview of Chinese Opera in Southeast Asian, Chinese Opera Press, January 1993, Page 190.

25 Lai Bojiang, Huang Jingming. History of Guangdong Opera. Chinese Opera Press, July 1988, Page 360

26 Spread to Foreign Countries. Hubei Historical Accounts of Past Events, Z1, 1998, Page 198 many amateur Han music organizations were carrying out activities. $^{27}$

Quanzhou Liyuan opera was spread to Southeast Asia very early. In 1925, Shuangfengzhu Troupe, led by Zeng Shendai, went to Indonesia Surabaya to perform traditional plays, Chen San and Wu Niang and Xue Mei Teaching Son. ${ }^{28}$ In 1928, Xinfu Music Troupe, a Fujian opera troupe, went to Surabaya, Semarang and other places of Indonesia for performances. The main plays were Cry of Prince, Yan Lan Dream, Ling Zhi Cao, Chen Xingyuan's Marriage for Peace. The actors of this troupe were productive in roles. They could act Xiaosheng, Laosheng, Wusheng, Huadan, Wudan and Erhua and other roles. They were good at the unique skill "Ti Du": standing on one foot as the cock does, fiddling with hair with one foot, kicking above shoulder with one foot, twisting one leg on waist or one leg on the other leg. The actions were quite light and agile, and appreciated by local oversea Chinese. ${ }^{29}$

From 1920 to 1930, there were a lot of Chinese opera performance places in Indonesia. And performing activities were quite frequent. In Jakarta and Surabaya and other ports, many local overseas Chinese leaders and capitalists operated indoor theatre and open-air stage. ${ }^{30}$ In this period, troupes of Chinese song and dance drama also went to Indonesia for performance, in addition to Guangdong opera, Han opera, Fujian Opera and Liyuan opera. In 1928, Shanghai's Mingyue Song and Dance Troupe, led by famous musician and modern dancer $\mathrm{Li}$ Jinhui, went to Bandung and other places of Indonesia for performance. The main plays were Grape Fairy Maiden, Sparrow and Child, Moonlit Night, Little Painter, Drizzle, Sister, I Love You and Poor Qiuxiang. In the winter of 1932, Shanghai's Meihua Song and Dance Troupe went to Indonesia for performance. Their main actors were $\mathrm{Xu}$ Canying and others. The main acts were Taohua River, Seaman Dance, Toe Dance and A Spring Dream. They had aroused strong repercussions in the local places. Some songs were sung for a while. Some parts were performed by teachers and students of school for overseas Chinese. ${ }^{31}$

During the Anti-Japanese War, Chinese opera in Indonesia was upstaged by drama. The anti-Japanese surge swept across the oversea Chinese circle. Opera actors began to organize flexible troupes to perform anti-Japanese propagate play. Modern drama came into fashion. At that time the main Indonesian drama groups were Youth Drama Society's Bo'ai Opera Troupe, Palembang's Freedom Society, Cirebon's Free Youth Society, Bandung's Guofeng Opera Society, Surabaya's Qingguang Drama Society, Malang's Youth Drama Association, Xijiang's Xingxing Club and Semarang's

\footnotetext{
27 Lai Bojiang. History and Current Situation of Chinese Opera in Southeast Asian. Published in Opera Art, Issue 3, 1995, Page 50

28 Chen Lei, Liu Xiangru, Lin Ruiwu. Fujian's Local Operas. Fujian People's Publishing House, July 1997, Page 30.

29 Lai Bojiang. Overview of Chinese Opera in Southeast Asian, Chinese Opera Press, January 1993, Page 199 - 200.

30 Lai Bojiang. Overview of Chinese Opera in Southeast Asian, Chinese Opera Press, January 1993, Page 195.

31 Lai Bojiang. Overview of Chinese Opera in Southeast Asian, Chinese Opera Press, January 1993, Page 137 - 138
} 
Southern Star Club. ${ }^{32}$ These members of the societies mainly were youth, students and some literature and art lovers. They were mainly fundraising performances, such as, funfest fundraising performance, fundraising performance for the nation's father's birthday, fundraising performances for the National Day and other anniversaries. The types of drama mainly were drama, song and dance play, Taiwanese opera and street cry. Put Down Your Whip was one of the most popular anti-Japanese plays among oversea Chinese in Indonesia. It was not until the end of the Second World War that the opera activities were restored to the scale of the prewar period.

\section{THE PROSPERITY AND DECLINE OF CHINESE OPERA IN INDONESIA}

The 20 years after the war is the last golden age of Chinese opera in Indonesia. The main reasons for the prosperity of Chinese opera in this period are the rise of nationalist enthusiasm of overseas Chinese and the friendship between Indonesia and China. Chinese theatrical troupes frequently visited, and China's new ideas were spread among Indonesian Chinese. "Literature and art follow the mass line". Amateur theatrical troupes in various places had performed traditional dramas which were popular with the masses. Chinese newspapers and periodicals were free to discuss and criticize. Huang Dongping, a famous Indonesian Chinese writer, once said, "at that time, all kinds of cultural and artistic activities in China, especially in drama, dance and music, became the norm of learning and performing in overseas Chinese communities and schools in Indonesia1.

In 1950s, the main overseas Chinese art groups in Indonesia were Jakarta's Xinyi Society, Chinese Chorus Group and Chinese Music Association and Bo'ai Opera Society; Bandung's Guofeng Opera Society, Seagull Opera Society and Chinese Opera Society, Yedao Literary Society; Surabaya's Huaguang Group, Chinese Music Society, Facing Sun Group and Qingguang Club; Medan's Xinzhongyi Art Troupe, Kunlun Art Group, Silian Opera Society; Kota Palembang's Qunsheng Drama Society, Chinese Drama Society; Xijiang's Overseas Chinese Troupe; Pontianak's Chinese Choir Group; Xianda's Xinmin Drama Society and Jambi's People's Voice Society. ${ }^{34}$ Under active organization of these overseas Chinese literary groups, public performances were showed in various varieties and wonderful contents. It included modern drama, opera, Fujian opera, Guangdong opera, Peking opera, Huangmei opera, Han opera and so on. The representative modern dramas were Facing the Sun, White Haired Girl, Qu Yuan, Liu Lianying, Before the coming of the New Director, Story of Sons and Daughters, Thunderstorm, True Story of Ah $\mathrm{Q}$ and Tianxia Weigong; the song operas were Opening Up Wasteland, Pipa Ci, The Peacock Flies to Southeast, Song of

32 Wu Peifang. Study of Oversea Anti-Japanese Opera Show - taking opera movements in Southeast Asia from 1937 to 1945 as example. Publishing in Fuxinggang Journal, 2005, Issue 83, Page 157.

33 Huang Dongping. Speech in the third National Taiwan, Hongkong and Overseas Chinese Literature Symposium in Shenzhen. Published in Huang Dongping Anthology, Volume 10, Mutual Fund Ministry of Culture of Indonesia Jakarta Kinmen, 2003, Page 159.

34 Huang Kunzhang. History of Indonesian Chinese (1950 - 2004), Guangdong Higher Education Press, January 2005, Page 130.
Grassland, Story of Chun Xiang; Fujian operas were Chen San and Wu Niang, Qin Xianglian, Changing Litchi for Peach and Replacing Limao for Prince. Guangdong operas were Bao Lian Deng, Hua Rongdao and Wang Zhaojun; Peking operas were the Cowherd and the Weaving Maid, Dongping Palace, Lost Jieting, Liang Shanbo and Zhu Yingtai, Empty City and Xiao Fang Niu; Yu opera includes Mulan. ${ }^{35}$

In July 1956, to celebrate the opening of Semarang Guangzhao Guild Hall, Surabaya's Lubei Amateur Troupe performed Fan Zhong Visiting Xi Shi, Tang Bohu and Qiuxiang, Liang Shanbo and Zhu Yingtai, Guan Zhong Visiting Huan Gong publicly. Longchuan's Guangzhao Entertainment Group also staged a wonderful opera Buy Marriage, causing a large influence. ${ }^{36}$ On June 9, 1957, Minsheng Society and Amateur Society jointly performed Song of Grassland publicly. After ten months of preparation and rehearsal, it was presented to audiences in Yecheng. The main actors were Fu Shengchang and Chen Xieli. The performance was very successful and received good praise from all walks of life. In particular, the orchestra for the accompaniment of the opera played very well and received the unanimous admiration of the audience. ${ }^{37}$ In 1959 , for the celebration of the 10th anniversary for the foundation of People's Republic of China, Jakarta's Xing'an Association performed a Puxian opera Battle in Chibi1. At the same time, Surabaya's Xianxi Society performed After Reunion. This play had ever created a stir in joint opera performance in Beijing, and was listed as best screenplay. ${ }^{38}$ In Indonesia, there were lots of oversea Chinese and Chinese Indonesians, original native of Putian and Xianyou. They had strong provincialism, so Puxian opera was particularly favored by the audience. At that time, some records of Puxian opera were sold out once appeared in Jakarta. ${ }^{39}$ Xing'an Association also performed Borrow Daughter for Good Luck, a play of Puxian opera.

At that time each troupe of oversea Chinese produced various local operas and the performance pomp was unprecedented. They were very popular. Every night huge crowds of assiduous people came to see performance. "some audiences even watched same play for several times". ${ }^{40} \mathrm{In}$ 1961, Jakarta's Yurong Association launched Fujian operas, including Madame White Snake and Story of Liu Yi, creating

35 Huang Kunzhang. History of Indonesian Chinese (1950 - 2004), Guangdong Higher Education Press, January 2005, Page 131.

36 See stage photos on Commemorative Journal for the Completion of New Guangzhao Hall in Semarang, Java, Indonesia, July 1, 1956.

37 Zhou Yingnan. Xinghua's Local Opera: War in Chibi. Published in Tang Jianping's Yilan Shenghui - Zhou Yingnan Collection (Volume I). Xiamen University Press, March 2001, Page 326 - 327.

38 Zhou Yingnan. Puxian Opera in Southeast Asia. Published in Tang Jianping's Yilan Shenghui - Zhou Yingnan Collection (Volume I). Xiamen University Press, March 2001, Page 328 - 329.

39 Zhou Yingnan. Puxian Opera in Southeast Asia. Published in Tang Jianping's Yilan Shenghui - Zhou Yingnan Collection (Volume I). Xiamen University Press, March 2001, Page 328.

40 Zhou Yingnan. Madam White Snake and Borrow Daughter for Good Luck - Two Touching Local Operas, Published in Indonesian Language Learning, Issue 10, 1961, Page 23. 
a great sensation. ${ }^{41}$ In 1964, Yurong Association performed Blood Fingerprints in the City Opera Theatre of Jakarta. Association of Shandong showed a traditional Pecking opera Jin $\mathrm{Yu} \mathrm{Nu} .{ }^{42}$ At the same time, Chinese Journal actively commented these performances. For example, it published several review articles on Study of Indonesian, 10th issue, 1961. It included Zhou Yingnan's Two Touching Local Operas - Madame White Snake and Borrowing Daughter for Good Luck and Yun Ni's Impressions on Yecheng Yurong Association's Fujian Opera Madame White Snake, and Notes on Madame White Snake, written by Nong Fu, Yi Ding, Xun Sheng, Jian Feng and Xiao Dong. ${ }^{43}$ In 1964 , another event in Chinese theatrical circle was the public performance of largescale song and dance opera Liu Sanjie. After eight months of rehearsal, Jakarta's Nan'an Association and Xinyi Society mobilized more than 400 staff and jointly performed this opera.

Indonesian Chinese's opera show has been active for half a century. They basically were traditional Chinese plays. In 1960s, Indonesian Chinese's local consciousness awakened and once proposed the literature and art view of facing Indonesian, replacing the original view of facing homeland and Chinese. But it was too late, because in 1965, the Suharto regime launched "Jiusa Movement". Indonesia began to repel Chinese. The government took steps to carry out all kinds of Chinese culture-limited political strategies. They forbidden from using Chinese, publishing and importing Chinese newspapers and books, and only left Indonesian Daily, half in Chinese and half in Indonesian, to propagate political strategies towards Chinese. They forbidden from importing and circulating Chinese records, tapes and videos, performing Chinese song and dance operas, and keeping Chinese cultural customs, and banned all overseas Chinese organizations and so on. In October 1967, the Indonesian government announced the interruption of diplomatic relations with China. The Indonesian authorities were more stringent on the policy of restricting Chinese education and literature and art. In June 1976, the supreme prosecutor issued No. 29 written decision of administrative. It prohibited the use and import of cassette recordings, videos and records in Chinese or Chinese dialects, and banned Chinese videos. Despite repeated prohibition, the 13th presidential decision, issued in March 1983, further measures specified for the import videos and tapes, and further prohibited the importation and reproduction of Chinese videos. In the mid $80 \mathrm{~s}$, Chinese Taijiquan, accompanied by Chinese music, must also be renamed "Indonesian Therapy Exercise", with Indonesian Music. ${ }^{44}$ In April 1989, Taiwan's Chinese Opera Troupe went to Indonesia and performed Madam White Snake, Ancient City Fair and other plays. The tickets were sold out quickly. But several hours before performance, the authorities banned the performance. The reason they gave was that "it destroys the movement of Chinese assimilation and

41 Yun Ni. Review on Madam White Snake, Yecheng Yurong Society's Performance. Published in Indonesian Language Learning, Issue 10, 1961, Page 24.

42 Theatergoer. Review on Jin Yu Nv, Peking Opera. Published in Indonesian Language Learning, Issue 10, 1961, Page 26.

43 Xiao Dong. Review on Madam White Snake. Published in Indonesian Language Learning, Issue 10, 1961, Page 26.

44 Huang Kunzhang. History of Indonesian Chinese (1950 - 2004), Guangdong Higher Education Press, January 2005, Page 179 - 180. hurts the national interests of Indonesia, and possibly leads political problems". ${ }^{45}$ In June of the same year, Indonesian troupe of Medan planned to perform Liang Shanbo and Zhu Yingtai, and also got approval of the cultural department. Tickets have been sold. But the local government banned in the performance day. ${ }^{46}$

Indonesian Chinese opera entered into a harsh "freezing period". In view of the fact that the Indonesian government is a weak government, the validity of the decree is doubtful in the remote areas and among bottom people. Chinese opera still continues in the form of folk roots. For example, in Indonesia, puppet show has been popular for a long time in Indonesia. Even in those harsh years, there were still puppet shows. John Chin has made a detailed analysis of puppet show performance situation in the period in his research on Chinese puppet show in Indonesia. In the folk people were used to invite people to perform puppet show when they pray god for booming business, good examination achievement and happy marriage1. In the late 1980s, Indonesia gradually recovered cultural exchange with China. The tiny change of Indonesian authorities unfroze Chinese education and literature and art prohibition, and entered into a revival period. But the unfreezing process was still slow. The establishment and development of an art tradition is slow and hard. Once it is interrupted, the revival will be more difficult. The relaxed political and racial environment, the preparation of language foundation, the acceptance of mass literary habits, and the cultivation of the qualities of writers need efforts and time accumulation.

\section{CONCLUSION}

In Indonesia, Chinese opera has experienced stages of rise, prosperity and decline in the 1920s. Due to the special political situation in Indonesia, Chinese drama activities are quite colorful, but the script creation is relatively weak. The scripts written by local writers and reflecting overseas Chinese life are rather limited. We know the tortuous course of Chinese opera, reflect on the problems, examine its cultural values, and look forward to its future development. Indonesia is one of the countries with the largest number of overseas Chinese in the world. There are about 6000000 Chinese in Indonesia. They play a decisive role in the national economy and political, ideological and cultural life in Indonesia. Unfortunately, compared with Chinese drama creation in Singapore and Malaysia, the development of Indonesian Chinese drama is obviously insufficient, which is disturbed by political and racial factors. In the reality of political turbulence, racial separation and cultural diversity, drama is often more vulnerable than literature, because the social factors it involves are more complex and have greater impact on social reality. So, it is also more politically sensitive and more vulnerable to the impact of political movement. Chinese opera shows in Indonesia and creation tradition have been long-standing, and

45 Paris, European Times, April 21, 1989, quoted from Huang Kunzhang's History of Indonesian Chinese (1950 - 2004), Guangdong Higher Education Press, January 2005, Page 180.

46 Kuala Lumpur, Sin Chew Daily, June 25, 1989, quoted from Huang Kunzhang's History of Indonesian Chinese (1950 - 2004), Guangdong Higher Education Press, January 2005, Page 180. 
were ever prosperous. But due to purely political reasons, it was near extinction in nearly half a century. Something is worth thinking about. The catastrophe ever happened, and it is possible to come again.

\section{REFERENCES}

[1] Egu - Sumaer. Translated by Lin Wanli. Research on Malayu Literature of Indonesian Chinese. Hongkong: Huoyi Publishing Business Co. Ltd., 1998. 耶谷 - 苏玛尔卓著, 林万里译: 《印尼侨生马来由文学研 究》, 香港:获益出版事业有限公司,1998 年。

[2] Liang Minhe and Kong Yuanzhi, Indonesian Culture and Society, Beijing: Peking University Press, 2002. 梁敏和、孔远志编著: 《印 度尼西亚文化与社会》, 北京: 北京大学出版社,2002 年。

[3] Chen Lei, Liu Xiangru, Lin Ruiwu. Fujian's Local Operas. Fuzhou: Fujian People's Publishing House, 1997. 陈雷、刘湘如、林瑞武: 《福建地方戏剧》, 福州:福建人民出版社,1997 年。

[4] Liang Liji. History of Indonesia Literature. Beijing: Kunlun Press, 2003. 梁立基: 《印度尼西亚文学史》, 北京:昆仑出版社,2003 年。

[5] Lai Bojiang. Chinese Drama in Southeast Asia, Beijing: Chinese Drama Press, 1993. 赖伯疆: 《东南亚华语戏剧概观》, 北京:中国戏剧出 版社, 1993 年。

[6] Wu Fengbin, [Dutch] Chen Menghong, [Dutch] Bao Leshi, Nie Dening: Chinese Council in Batavia (Batavia Tribunal) Archives Series Case Book (fifth series), Xiamen: Xiamen University Press, 2005. 吴凤斌、 [荷]陈萌红、[荷]包乐史、聂德宁校注：《吧城华人公馆（吧国公 堂) 档案丛书公案簿 (第五辑) 》, 厦门:厦门大学出版社,2005 年。

[7] Spread to Foreign Countries, Hubei Historical Accounts of Past Events, Z1, 1998. 《向国外传播》，《湖北文史资料》,1998 年 Z1 期。

[8] Huang Dongping. Huang Dongping Anthology. Indonesia Jakarta: Kinmen Mutual Fund Ministry of Culture, 2003. 黄东平: 《黄东平 文集》，印尼雅加达:金门互助基金会文化部,2003 年。

[9] Huang Kunzhang. History of Indonesian Chinese (from 1950 to 2004). Guangzhou: Guangdong Higher Education Press, 2005. 黄东平: 《黄 东平文集》，印尼雅加达:金门互助基金会文化部,2003 年。

[10] Tang Jianping. Yilan Shenghui - Zhou Yingnan Collection. Xiamen: Xiamen University Press, 2001. 黄东平: 《黄东平文集》, 印尼雅 加达:金门互助基金会文化部,2003 年。

[11] John B. Kwee, A Study of Potehi, Chinese Puppet Theatre in Indonesia, ASIAN CULTURE 20, 1996. 